\title{
The Law as a Weapon in Marital Disputes: Evidence from the Late Medieval Court of Chancery, 1424-1529
}

\author{
Sara M. Butler
}

When Isabelle, widow of Richard Vergeons, commissioned the writing of a bill of complaint to Chancery at the end of the fifteenth century, she was clearly at the end of her tether. Six months before the writing of the petition, the wife of Thomas Hyll, a wire monger of London, approached the petitioner's husband, begging for "secour and saufgarde of her lyf." She was driven to this request only after "dyvers variantes and discordes betwene her and the seid Thomas her husbond and for grette fere and inpartye that the seid Thomas put to her of her lyf." When Richard happened upon her she was being chased by Thomas, who was wielding a dagger. Seeing "the ungoodly and hasty disposition of the seid Thomas and the greate fere of his seid wife," Richard decided to take matters into his own hands. He received Thomas's wife into his home and then confronted Thomas about his actions, hoping to reason with him and convince him to treat his wife appropriately. This soon proved to be a fatal error. According to the plaintiff, "Richard entreted and desyred the seid Thomas to take his seid wif to hym ageyn and to gyde her and chastice her under a due maner and not to draw his dager to her and the seid Thomas annswered yf he myght mete wit his seid wyf he wold utterly slee her and the seid Richard seyng his ungodly disposicion kept her in his hous tyll anone after by the false and myschevous labour \& procurement of the seid Thomas the seid Richard then husbond unto your seid oratrice was slayn at

SARa M. ButLer is a postdoctoral fellow at Saint Mary's University, Halifax. Funding for this research was generously provided by the Social Sciences and Humanities Research Council of Canada postdoctoral fellowship, held at Saint Mary's University in Halifax, Nova Scotia. I am also indebted intellectually to the following persons for their comments on earlier drafts of this article: Cynthia Neville, Tim Stretton, Charles Donahue, Jr., Melissa Furrow, and Shannon McSheffrey, as well as the anonymous reviewers for the Journal of British Studies. Any errors or omissions are, of course, my own. Finally, many thanks to Tim Haskett for a variety of searches in the Early Court of Chancery in England (ECCE) database.

Journal of British Studies 43 (July 2004): 291-316

(C) 2004 by The North American Conference on British Studies.

All rights reserved. 0021-9371/2004/4303-0001\$10.00 
his owne dore in London." Richard's death only strengthened Isabelle's conviction to shelter Thomas's wife from her brutish husband. Isabelle locked her home and refused to allow Thomas near his wife, but he was not so easily dissuaded. Thomas made repeated threats on Isabelle's life and then quite shrewdly turned to the courts to continue his assault. $\mathrm{He}$ sued a plea of trespass against Isabelle and arranged with the sheriff of London to hold an inquest into the action. Fearing imprisonment or worse, the newly widowed Isabelle threw herself on the mercy of the chancellor. ${ }^{1}$

The extant documentation of the early Chancery proceedings do not offer any evidence to explain how this case was resolved. Unfortunately, for the medieval period, in general, the records of the court's daily business have not survived, only the bills of complaint brought to it; nor have any responses to the petitions or the court's decisions been preserved. As a result, it is possible to discover what kinds of cases the court addressed, but it is much more difficult to know how they dealt with them. Nevertheless, the plight of Isabelle Vergeons confirms that the records of the medieval court of Chancery have much to offer historians when it comes to an investigation of marital disharmony. Thomas Hyll was not the only angry husband in late medieval England to put the courts to use in a dispute against his wife and her protectors. Marital disharmony in late medieval England often had a definite legal dimension. Medieval litigants exploited England's expansive and heterogeneous judicial system by pleading suits relating to marital spats in a wide variety of venues, from the courts Christian to common-law and manorial courts. ${ }^{2}$ Cases like that of Isabelle Vergeons, however, demonstrate that the development of Chancery as a court of appeal by the second half of the fifteenth century provided litigants an additional, and even more powerful, option in the resolution of domestic disputes. The records of the court of Chancery offer an

${ }^{1}$ Public Record Office, London (hereafter abbreviated as PRO) C1/82/87, Isabelle, late the wife of Richard Vergeons v. Thomas Hyll, wiremonger of London, brother-in-law of complainant (ca. 1487-1503). Unfortunately, it is difficult to date many of the Chancery documents because the bills themselves do not provide any indication of the year. For the purposes of this article, I have attempted to date each bill according to chancellor. This was not an easy undertaking. Often, the only clues to the identity of the chancellor in the bill may be an address of the following sort: "to the Ryght reverent fader in god the Bisshop of Excester and channceler of Englond." This address, in combination with the bundle number, was used to approximate the dates for the bills; the dates were then checked against Timothy S. Haskett's brief guide of sample periods used for the ECCE Project and published in his “The Medieval English Court of Chancery," Law and History Review 14 (1996): 283.

${ }^{2}$ R. H. Helmholz, Marriage Litigation in Medieval England (Cambridge, 1974); Barbara A. Hanawalt, "Females as Felons and Prey in Fourteenth-Century England," in Women and the Law, 2 vols., ed. D. K. Weisberg (Cambridge, 1982), 1:180; Robert C. Palmer, "Contexts of Marriage in Medieval England: Evidence from the King's Court circa 1300," Speculum 59 (1986): 42-67. 
opportunity to witness marital disputes of an unusual nature, highlighting the weapons of a highly litigious society. Chancery's petitioners paint a picture of a world in which hired thugs and false suits become the most effective weapons in marital warfare, saddling unsuspecting spouses or their rescuers with costly legal fees, unjust prison terms, and, as the case of Isabelle Vergeons suggests, sometimes painful casualties.

The court of Chancery also provides valuable insight into the process of marital breakdown. Physical abuse, spousal separations, and maintenance agreements all make an appearance in the court of Chancery on various occasions. The bills of petitioners, then, illuminate the inherent tensions in medieval society that led to marital breakdown. For example, in the case presented by Isabelle Vergeons, the very language of her petition points to a tenuous balance between discipline and abuse in marriage, while simultaneously illuminating contemporary expectations of gendered behavior. When Thomas pursued his wife through the streets of London with a dagger in hand, Richard willingly stepped in to put an end to this "ungodly" behavior. His request that Thomas take his wife home and "gyde her and chastice her under a due maner" invites a number of interesting conclusions. First, Richard explicitly acknowledged Thomas's right to correct his wife, if only in the name of chastisement, but that right had identifiable limits that did not include attempted homicide. Second, Isabelle, as a woman in a similar position, also recognized Thomas's claim to use physical force with his wife. In fact, she appears to have agreed wholeheartedly with her husband's request that Thomas curb the degree of force rather than eliminate it altogether. This suggests that when trying to get a trespass case removed to Chancery, "chastisement" as a form of physical discipline for one's wife was socially approved and internalized by both genders in the medieval community.

Chancery bills also provide some insight into the regular process of dealing with marital disharmony within the context of the medieval community. When it became obvious that Thomas's murderous rampage would continue, Richard and Isabelle volunteered themselves as protection to Thomas's wife and willingly moved her into their home. Richard and Isabelle were motivated in their actions by an existing family relationship rather than a simple desire to be neighborly. At the beginning of her petition, Isabelle identifies Thomas as her brother-in-law, although she does not give any clue as to the exact nature of the relationship, that is, whether Thomas's wife was sister to her or to her husband. ${ }^{3}$ Whether

\footnotetext{
${ }^{3}$ Given the disparity in names between the two men, it seems likely that the blood relationship was between Thomas's wife and the couple, rather than between Thomas and Richard.
} 
through family allegiance or custom, families were thought to be primarily responsible for the arbitration of marital discord in cases of explicit abuse, indicating that when protection of the woman was required it was natural for her to turn to her family rather than an official of the court.

\section{The Court of Chancery and Its Value to Historians of Marriage}

Although rarely exploited by medieval historians, petitions to the court of Chancery have much to offer in terms of highlighting the role of women in medieval England. Recent studies have demonstrated that medieval women felt most comfortable in the legal setting of the court of Chancery. In an examination of bills of complaint sent to Chancery between 1461 and 1515 by petitioners living in Yorkshire, Emma Hawkes notes that fully 15 percent of the litigants were female. These figures have led her to argue "that women were significantly more likely to participate in legal activities in equity than in common law courts." Moreover, she argues that Chancery bills appealed to notions of chivalry, "calling on the idea that the king should be the friend to the friendless, caring for widows and children. The use of this ideology may have made Chancery a more attractive jurisdiction for women." ${ }^{4}$ Timothy Haskett has made a similar argument. ${ }^{5}$ No study of marital disharmony in the medieval period, then, would be complete without an investigation of the records of the court of Chancery. ${ }^{6}$

Of course, the records of Chancery present some insurmountable problems for the historian. In terms of marital disharmony, whether the alleged victim actually experienced the level of abuse indicated in these bills we may never know. It is all too possible that these bills represent a degree of fiction intended to gain a sympathetic ear. ${ }^{7}$ What we do know, however, is that the petitioner strongly believed that by telling the

${ }^{4}$ Emma Hawkes, “'[S]he will ... protect and defend her rights boldly by law and reason...': Women's Knowledge of Common Law and Equity Courts in Late-Medieval England," in Medieval Women and the Law, ed. Noël James Menuge (Woodbridge, 2000), pp. $151,155$.

${ }^{5}$ Haskett, "Medieval English Court of Chancery," pp. 288-89.

${ }^{6}$ It was simply not possible to peruse sixty-one thousand bills of Chancery. Instead, I chose to examine all three volumes of the List of Early Chancery Proceedings. Although the case summaries included in these volumes are exceedingly brief and sometimes misleading, they were sufficiently detailed to allow me to discern those cases related to marital disharmony, and any cases in which husband and wife appeared as petitioner and respondent. See Public Record Office, List of Early Chancery Proceedings, vols. 1-3, Public Record Office Lists and Indexes nos. . 12, 16, 20 (London, 1901, 1903, 1906; reprint, New York: Kraus, 1963). The Public Record Office's computerized catalog (PROCAT) was used to supplement this primary search.

${ }^{7}$ In cases of domestic violence, litigants may have been accustomed to embellishing their stories. See Sara M. Butler, "Lies, Damned Lies, and the Life of Saint Lucy: Three 
chancellor about these events she (or he) would improve her chances of securing his intervention. Consequently, these petitions offer plentiful insight into a world the chancellor was intended to find reprehensible. Although the chancellor's decisions have not survived, it seems likely that the petitioners achieved this goal. These cases provide a perspective of what medieval men and women found unacceptable in matrimonial disputes.

A degree of fiction is apparent in the case of Isabelle Vergeons and Thomas Hyll. If witnesses could prove that Thomas Hyll had assaulted and slain Richard Vergeons, or even that he was likely to have done so, a coroner almost certainly would have arrested him, making Hyll unable to sue a case of trespass against his victim's wife. That he was not diminishes the reliability of Isabelle's story. It is possible that Richard's death was an unwitnessed assault that Isabelle believed was related to the hostility between Thomas and her husband, yet she had no proof of his involvement. The fact that she was merely requesting a grant of certiorari to have her case heard before Chancery rather than the local sheriff also reveals that her evidence of Thomas's villainous actions was weak and unconvincing. If the petitioner's story is to be believed, then, Thomas's suit in court against her was possibly an attempt to silence his victim's wife before she had the opportunity to finger him - if the petitioner's story is to be believed. It is also possible that Isabelle invented the entire incident and her husband died a natural death. Without all the facts, historians are inevitably required to assume the role of detective, ferreting out any niggling, gnawing glimpses of fabrication and providing the best explanation possible given the evidence. To return to Isabelle's case, while it is clear that there is more to this story than meets the eye, it is also unlikely that her story represents pure invention. For example, a cursory investigation of coroners' rolls for the city of London by the court's officials would easily uncover the known facts concerning her husband's death. ${ }^{8}$ Isabelle's narrative, then, would have to conform to this report in order to remain within the realm of credibility.

Historians are also constrained by the curial process. A paid clerk drafted all bills, just as a paid lawyer advised them. ${ }^{9}$ Mediation by a scribe or lawyer accounts for the generally formulaic structure of Chancery bills:

Cases of Judicial Separation from the Late Medieval Court of York," in Trompe-l'œil: Imitation \& Falsification, ed. P. Romanski and A. Sy-Wonyu (Rouen, 2002), pp. 1-16.

${ }^{8}$ Unfortunately, no coroners' rolls for this period have survived from the city of London in order to provide the opportunity to check the facts.

${ }^{9} \mathrm{P}$. Tucker has suggested that Chancery bills "were sometimes composed and perhaps even written by the plaintiff himself." See P. Tucker, "The Early History of the Court of Chancery: A Comparative Study," English Historical Review 115 (2000): 791-811, quote on 791 . 
formal greeting, detailed account of predicament, formal request for help. Nonetheless, amidst the tedium of protocol and legal necessity emerge the voices of the victims of abuse. Unlike other medieval court records, Chancery bills of complaint ordinarily were written in English and were quite verbose. ${ }^{10}$ The reader is thus able to see how the victim would have phrased the abuse in words familiar to him or her. To say that a woman non audet cohabitare cum eius virum (does not dare live with her husband) gives us little perspective into how a beaten wife personally would have described her situation. This phraseology regularly employed by the church courts was merely a formula used by court clerks to deal with a standard legal issue. ${ }^{11}$ In the English court of Chancery, however, there were no fixed procedures, let alone such a standardized vocabulary. Reading Margery of Longford's words to the chancellor that "she was sore aferd of hyr sayde husbond," and Alice, wife of George Softley of Latton's that her husband "so hurt and bette her that she was therby in perell of her liff," we are given an opportunity to hear the victim's side of the story in the wars of matrimony. ${ }^{12}$

The versatility and effectiveness of Chancery made it the ideal venue for resolution of marital disputes. For example, while late medieval common-law justices were able to award damages for the nonperformance of an oral or written agreement, this was the limit of their abilities. Chancery, on the other hand, was capable of both awarding damages and ordering the performance of the agreement. ${ }^{13}$ In spousal disputes, this provision meant that the courts might enforce effectively maintenance contracts for separated wives. While the church courts were capable of addressing this issue (and often did), they provided inferior solutions. Excommunication, public penance, fines, and monitions only went so far. Chancery could have the delinquent husband arrested and cast in prison (without waiting the forty days required by the law of caption) and compel performance of the agreement. To a woman without any immediate support, Chancery undoubtedly offered the most expeditious solution.

${ }^{10}$ Early bills were usually drafted in French (although some were certainly in Latin). All but one of the cases relevant to this study is in English.

${ }^{11}$ The phrase "non audet cohabitare cum eius virum" was regularly used in libels or depositions for cases of judicial separation on the grounds of cruelty (saevitia) in the church courts of medieval England in order to meet the court's requirements that the extent of cruelty endangered the life of the spouse. For example, see York Borthwick Institute (YBI) CP. F 235/2, Agnes Benson v. Peter Benson (1448), or YBI, CP. G 35/1, Joanna Ireby v. Robert Lonesdale (1509).

${ }^{12}$ PRO, C1/6/318, Lady Margery of Longford v. her husband Richard of Clyderhowe (ca. 1424-25); PRO, C1/162/46, Alice, wife of George Softley of Latton, previously wife of Thomas Westwode of Latton, and Richard, son of the said Thomas and Alice v. George Softley of Latton (ca. 1504-9).

${ }^{13}$ Alan Harding, The Law Courts of Medieval England (London, 1973), p. 102. 
The records of the court of Chancery, however, demonstrate that English medieval society was still not comfortable with wives suing their husbands (or vice versa) and chose instead to keep within the rules of coverture in which husband and wife were considered one person under the law. ${ }^{14}$ Hence, for example, there are no identifiable cases of medieval wives using the court of Chancery to plead suits against their husbands for violent trespass. ${ }^{15}$ What the records do demonstrate is a shrewd use of the courts by both husbands and wives to work around the rules of coverture and dictate the terms of marital separation.

\section{Spousal "Abduction"}

Quarrels arising from informal separations were the most common type of complaint involving marital disharmony to appear in the court of Chancery. Frequently these cases appeared in Chancery in the guise of spousal abduction. In her study of trespassory ravishment of wives in the courts of King's Bench and Common Pleas, Sue Sheridan Walker makes some important discoveries relevant to the current investigation about the use of the terms "ravishment" and "abduction" in the medieval context. ${ }^{16}$ When a husband sued a plea in court for the ravishment of his wife, it was purely an economic plea-in the hopes of retrieving the value of the goods taken with her rather than the wife herself. Walker uses the term "consensual abduction" to describe the actions of these women. She argues convincingly that "the wives in question were probably not only willing but had their portable possessions packed awaiting the arrival of their abductors." 17 This legal fiction was recognized and accommodated by the royal courts of medieval England. Consequently, in a suit of ravishment, the plaintiff might request an award of damages, but the suitable writ could not also order the restoration of one's wife. Walker claims that this was an

${ }^{14}$ Tim Stretton has examined the difficulties associated with coverture and its impact on wives. See Tim Stretton, Women Waging Law in Elizabethan England (Cambridge, 1998), pp. 22-23.

${ }^{15}$ A writ designed specifically for the prosecution of husbands for violent trespass against their wives did exist, and thus cases of this nature should have rightfully belonged to the king's courts. Nonetheless, it is clear that wives, whether out of fear or ignorance, did not use the royal courts for this purpose; the records of Chancery, then, at the very least demonstrate that wives were not using this court to resolve straightforward issues of domestic violence. For a discussion of domestic violence in the king's courts, see Sara M. Butler, The Language of Abuse: Marital Violence in Later Medieval England (Toronto: University of Toronto Press, in press).

${ }^{16}$ Sue Sheridan Walker, "Punishing Convicted Ravishers: Statutory Strictures and Actual Practice in Thirteenth and Fourteenth-Century England," Journal of Medieval History 13 (1987): 237-50.

${ }^{17}$ Ibid., p. 239. 
explicit "extension of control by women over their lives and marriages," and that by allowing themselves to be abducted, unhappy wives were consciously acting out a wish to end their marriages. ${ }^{18}$ The fact that many of these abducted wives were involved simultaneously in cases of judicial separation in the church courts confirms that the abduction was, in fact, a variation on the theme of spousal desertion. While Walker notes that often the ravisher was the wife's lover, Henry Ansgar Kelly's recent work on ravishment confirms that the abductor was frequently anyone from a father helping his daughter out of an adulterous marriage, to a brother rescuing his sister from a coerced marriage. ${ }^{19}$ Most plaintiffs who appeared in the royal courts with pleas of ravishment, then, were persons who had abandoned all hope of repairing the marriage and who sought only compensation for the loss of goods and chattels taken during the abduction.

Chancery petitions concerning spousal abduction were, perhaps predictably, of an unusual type, and thus shed some much-needed light on the problems associated with this kind of informal divorce. In particular, they demonstrate that cases of consensual abduction were fundamentally disputes about the division of marital property. Generally, they began as typical cases of consensual abduction that had since gone very wrong. In the case of John Haket, a long time before his petition came before the court of Chancery, Nicholas Montgomery of Wiltshire had abducted Haket's wife Alice. Consensual abduction, however, was only the first step in his wife's decision to take control of the situation. According to Haket, since the abduction,

Nicholas and Alice have procured strange persones to lye in wayte for be seid supplicant to slee hym for ye wheche cause he hase purchased a writte of manace ayens hym and nowe it is soo fulgracyouse lorde pat ye seid Nicholas hase waged foure unknawen persones nonnsuffyciant wiche ou of hym for a noble in deceyt of oure soverayn liege lorde ye kynge and his court to be come maynpernes for ye seid Nicholas and Alice in ye seid court wherfore liketh to youre graciouse lordesship to charge ye court pat if any suche maynpernors come in to be seid court to undirtake for be seid Nicholas and Alice pat hor suffycyante mowe be knawen and if thay be founde disceyvable in pat partie pat thay may be punysshed after youre wyse discrecion in ensammple of other for goddes luf and in werk of charitee. ${ }^{20}$

${ }^{18}$ Ibid., p. 238.

${ }^{19}$ Ibid., p. 246; Henry Ansgar Kelly, "Statutes of Rapes and Alleged Ravishers of Wives: A Context for the Charges against Thomas Malory, Knight," Viator 28 (1997): 398-99.

${ }^{20}$ PRO, C1/71/139, John Haket v. Nicholas Moungumrey, alias Shyrley of Salisbury (ca. 1487-1503). 
Attempted homicide and legal harassment were crimes not easily prosecuted in the medieval courts of common law; and so, the English court of Chancery was indeed the appropriate forum for the resolution of Haket's problems. In the absence of any further details, it is difficult to surmise the exact circumstances of the abduction. A possible scenario, following Walker's argument, is that an unhappy relationship ended because of Alice's adulterous affair with Nicholas Montgomery. Only after she had achieved distance from her husband and had secured Nicholas's support did she decide to strike back.

Although the bill never specifies the nature of Alice's relationship with Nicholas Montgomery, it is possible that he was Alice's lover; otherwise, John most likely would have identified him as a family member or neighbor. This being the case, John's bill of complaint remains questionable. Why would Nicholas and Alice hire "strange persones to lye in wayte" rather than simply do away with John themselves? The numerous cases of murderous lovers appearing in the royal courts of medieval England suggest that the notion of wives and lovers joining ranks to terminate an unhappy marriage was not unimaginable. In this light, John's accusation is all too convenient. John's suit may have been simply a preemptive tactic intended to attract the attention of the chancellor before Nicholas and Alice had the opportunity to pursue their legal options. A trumped up charge of attempted spousal homicide would not have damaged his chances of obtaining redress and had the added benefit of punishing Alice and Nicholas for their actions. Whether Alice and Nicholas actually did make an attempt on his life or not, John's petition confirms that abduction was not necessarily the last move in matrimonial war.

Money was once again the central issue in the petition of Philip Cabull, a dyer of Bristol. When Philip married Margaret, widow of Philip Barthelmewe of Bristol, he suddenly found himself moving up in the world, but only for a short time. His wife's abrupt desertion after a brief period of marriage implies that social mobility was his only reason for marrying the widow Margaret. This fact may have become quickly apparent to his new bride. It is also possible that Philip was abusive, or he had deceived her about his own wealth, and the truth had only come out after their wedding day. Whatever the reason, Margaret was unwilling to remain in his household. While he was away in London, Margaret's sons, William and John, stepped into action. With their mother's full "consent and agreement," they took her and goods and chattels reported to belong to her husband "of grete value the extente wherof the seid Orator knoweth not." They carried her away to the city of London where she had been in residence for a year prior to the petition. Since then, Philip was unable to 
"speke wit the said Margaret ne have eny parte of his seid good." Her sons, "by covyn and crafte between theym," allegedly sued numerous false actions of debt against Philip in court, "contrarie to all right and conscience" and egged on "by the procuryng and steryng of the seid Margaret." Moreover, "intendyng utterly to undoo her seid husbond," Philip reports that Margaret had two obligations drawn up for her sons in the sums of $£ 20$ and $£ 100$, respectively, falsely bearing a date before their spousals had taken place. Philip's request to the chancellor, nonetheless, reveals that there was more to the story than he wished to admit. Instead of a simple demand of reparation for the goods stolen from him by his two vigilante stepsons, he requested that a writ of subpoena be directed to them requiring them to appear in court before the chancellor bearing the false obligations, and then an injunction to be issued against them, preventing them from bringing further actions against the petitioner in court. If the stepsons had indeed abducted their mother and taken goods belonging to the petitioner as he asserted, he should have demanded damages or compensation for the value of the goods. The accusation of false documents is an indication that Margaret's motivation in escaping Philip was an attempt to safeguard her sons' inheritances before Philip spent it. ${ }^{21}$

Whether or not the actions sued against Philip were legitimate, Margaret's two sons probably had reasonable concerns about their inheritance and about their mother's happiness. At the very least, Philip had the decency not to protest his own innocence in the matter overtly, as did Richard Ores in his petition before the court. According to the latter's bill of complaint, he had endured many inequities at the hands of William Harryson. Ores had been defamed, compelled to perform public penance for a sin that he had not committed, and had had false suits brought against him in court. Moreover, Harryson had compounded his sins against Ores by carrying away his wife and goods from his home. Despite Harryson's allegations, with a clear conscience Ores was able to assert that he was "as giltlesse therin as the chyld born this nyght." 22 It is unlikely that many of the petitioners who appeared before the chancellor were as virtuous as Ores claimed to be. Complainants resorted to the courts as a means of both redress and coercion when a marital dispute escalated in nature. Both parties employed this tactic. As the various petitions examined in this study suggest, many complainants were already facing suits against them in the courts of common law. Still, while the king's courts proved to be useful weapons in domestic warfare, the English court of Chancery was a

${ }^{21}$ PRO, C1/83/38, Philip Cabull of Bristol v. William and John, sons of complainant's wife for abduction of complainant's wife (ca. 1487-1504).

${ }^{22}$ PRO, C1/343/57, Richard Ores v. William Harryson (1504-9). 
more powerful weapon. In bringing his case before Chancery, Ores could hope to receive compensation for his multiple losses.

In the case of Margaret Barthelmewe and her two sons, the circumstances of her abduction demonstrate all too clearly how very misleading the term "abduction" can be in cases of this type. William and John Barthelmewe were not abducting their mother for nefarious purposes; most likely, they were rescuing her from a marriage she saw as unsatisfactory. While Walker seems content to describe this as "consensual abduction," "assisted spousal desertion" is a more accurate description of the situation. These women chose to leave their husbands but needed the support of a loved one in order to carry out their plans. Once again, as we discovered in the case of Isabelle Vergeons, the intervention by Margaret's two sons shows that family members were the obvious choice. Similarly, when the daughter of William Morton of Bilburgh, Yorkshire, chose to leave her husband, it was her father who "abducted" her from her husband's home. ${ }^{23}$ To call these cases "abduction" rather than "desertion" makes a very powerful point: these men were not holding their wives legally responsible for their actions, nor could they.

Historians have studied the difficulties married women faced because of the rules of coverture in a variety of contexts, from property rights to civil liberties. However, they have sometimes overlooked the reality that husbands suffered similar restrictions. They, too, were incapable of initiating suits against their wives, because a suit against one's wife was essentially a suit against one's self. In the context of spousal desertion, a husband's powerlessness when faced with coverture becomes most apparent. Even though it is evident in all these cases that the respondent merely abetted the wife in a plan of her own design, the husband was required to hold the wife's lover, family member, or friend accountable. He could not sue his own wife for damages because, legally, a wife was incapable of stealing from her husband since the law viewed them as one person, and it is simply not possible to steal from one's self. This is one situation where the law of coverture benefited wives.

Cases of consensual abduction in Chancery, such as that of Margaret Barthelmewe, strongly suggest that what is at issue here is a question of the division of marital property upon separation. There were no fixed rules governing the distribution of property in situations of informal, or even judicial, separation. ${ }^{24}$ The church courts were capable of addressing the

${ }^{23}$ PRO, C1/492/ 35, Richard Chirden v. William Morton of Bilburgh, father-in-law of complainant (ca. 1515-29).

${ }^{24}$ As Maria Cioni has observed, it was not until the case of Elisabeth Walgrave v. Arthur Goldinge in 1581 that the court of Chancery chose to recognize this difficult situation 
issue of maintenance or alimony in cases of judicial separation, but an examination of the meager cases surviving demonstrates that there were no binding precedents and that enforcement was sporadic and ineffective. ${ }^{25} \mathrm{In}$ cases of consensual abduction, realizing that otherwise she had no recourse to the law to lay claim to any of this property, a wife probably left with all the possessions and deeds to land that she brought to the marriage. While there is no evidence to confirm that this is the case with Margaret Barthelmewe, this picture explains Philip's ignorance of his own property. When his wife left him, she reportedly absconded with chattels and goods "of grete value the extente wherof the seid Orator knoweth not." In the absence of documentation, the common law required him to know the exact details of the deed; his comment, then, simply reflects an explanation for why his case should rightfully appear in Chancery rather than the common-law courts. It is also possible, however, that he did not know the value of these goods simply because they were hers to begin with.

Even in cases where the bill does not couch the wife's desertion in terms of abduction, the same language of consensual abduction permeates the record. When Alice, wife of John Matheu de Tamall of Cornwall, decided that she no longer wished either the "felowschip ne governaunce" of her husband, she deserted him and took with her goods and chattels belonging to her husband. Matheu heartily believed that she had been encouraged in her decision by the "counsail and wykked ecitation" of two men, Walter Hankocke and Richard Martyn of St. Cue in Cornwall. Since then, she had not only come to despise her husband but also refused to "abeye his governance," and kept his property from him. Moreover, both Hankocke and Martyn "dayly vexe and troble" Matheu by "manessess and threteng in lesinge of his lyff" so that he might not comfortably "come in the felowship of hys wyff." In his petition to Chancery, Matheu directed his suit against Hancoke and Martyn, blaming them for "inducing" his wife to withhold his goods and chattels. ${ }^{26}$ Similarly, Nicholas

and provide a remedy for separated wives. See Maria L. Cioni, Women and Law in Elizabethan England with Particular Reference to the Court of Chancery (New York, 1985), p. 172 .

${ }^{25}$ An ex officio act book from Canterbury demonstrates that there might be quite a disparity. For example, while John Cok de Holyngham was required to pay his wife $12 \mathrm{~d}$. per week, the wife of William Bergh was to receive only $6 \mathrm{~d}$. per week from her husband. See Canterbury Cathedral Archives, Y.1.3, fols. 112 and 116. Comparatively, a York consistory court act book notes the case of Richard Wilkynson and his wife Margaret. In 1420 , when the couple approached the court to request a separation to which both parties unanimously consented, their property was divided equally between them, and the division itself was carried out by four arbitrators, two chosen by each party. See York Consistory Court $\mathrm{AB} / 1$, fols. $177 \mathrm{r}-177 \mathrm{v}$.

${ }^{26}$ PRO, C1/45/46, John Matheu de Tamall, yeoman v. Walter Hankocke and others of St. Cue (ca. 1467-70). 
Dobson's wife was also incited to leave her husband by the "inordinat demenying" of Richard Wymond, grocer of London. Richard caused "the wife of your said Oratour to be of no gode rwele" and "to absent hir from hir husbond," and had since "affermyd an untrewe and a fayned accion of trespace" against Dobson, for which he had been arrested and imprisoned. ${ }^{27}$

The language employed in the complaints of both Nicholas Dobson and John Matheu betrays the late dates of these petitions. In each, the petitioners carefully describe the problem as an issue of "poor governance" or "ill rule," which, as Barbara Hanawalt has persuasively argued, was a linguistic development of the late fourteenth century. Hanawalt has examined the shift between the uses of terms emphasizing reputation to those highlighting personal conduct. She argues, "the introduction of 'governance' implies a change in expectations for individual behavior. A person of 'ill repute' gains his or her bad reputation only by external labeling, but a community condemnation of 'bad governance' implies that a person should know better." ${ }^{28}$ Shannon McSheffrey has put forward an even more elaborate definition of the term "governance." She argues that it was not merely about personal conduct, but that being a man in late medieval society meant taking responsibility for the behavior of social inferiors as well as one's own conduct. ${ }^{29}$ Because, as McSheffrey contends, governance was intimately related to submission to a superior male authority, the situations of these women help to shed some light on the meaning of governance in this context. As the records describe it, both Nicholas Dobson's wife and Alice, wife of John Matheu, seem to have had very little control over their own ability "to be governed," having both been led astray by evil men. Their situations reveal that in late medieval England, a woman was of good rule if her husband ruled her; a woman was of ill rule if a man other than her husband (especially a lover) ruled her. In this equation, female independence was simply not an option; any man who permitted his wife to govern her own behavior was a poor excuse for a husband and a man. Not surprisingly, few men would have willingly appeared in court and confessed to being an utter failure as a man. Better to pin the blame for his wife's conduct on another man than to admit being married to an independent woman.

\footnotetext{
${ }^{27}$ PRO, C1/61/382, Richard Wymound, grocer v. Nicolas Dobson (ca. 1473-74).

${ }^{28}$ Barbara A. Hanawalt, "Good Governance' in the Medieval and Early Modern Context," Journal of British Studies 37 (1998): 248.

${ }^{29}$ See Shannon McSheffrey, "Men and Masculinity in Late Medieval London Civic Culture: Governance, Patriarchy and Reputation," in Conflicted Identities and Multiple Masculinities: Men in the Medieval West, ed. Jacqueline Murray (New York, 1999), pp. 243-78.
} 


\section{The Role of the Clergy in Spousal Abduction}

In her study of consensual abduction, Walker notes the frequency with which the courts identified clergymen as spouse abductors and proposes that these men "may have been acting in their capacity of spiritual advisor." 30 If a woman had no family or lover to rescue her from an abusive relationship, who better than the local priest, dedicated to the care of souls, to fill this role? A number of bills of this genre have survived from the early proceedings of the English court of Chancery. These cases demonstrate that marital disharmony had an impact on numerous people within a community, not just the couple and their lovers. In the case of Thomas Gwyn versus Thomas Colle, parson of the church of Combe Merton in Devonshire, Gwyn accused Colle of frequenting the family home in order to spirit away his wife. After four years of friendship with the couple, Colle came to the house of Thomas Gwyn and "toke away Johan the wiff of youre seid besecher all his goodes yit thar keepeth." These actions had, somewhat predictably in keeping with the requirements of the court of Chancery, "brought [the petitioner] in so grete povertee that he hath nothynge to sewe hym by the common lawe."31 Moreover, the parson had "by untrewe menes feyned accions" against the petitioner, and "hath soo labored ayenste youre forseide besecher [that] he der not come in to his cuntrey and thus utterly proposith to undo hym." Impoverished and harassed, Gwyn turned to England's chancellor for assistance. ${ }^{32}$

Gwyn's case offers little insight into the actual state of affairs between him and his wife; thus, it is only possible to speculate about the reasons why Colle felt it necessary to intervene in their marriage. For example, it is entirely possible that Colle was Joanna's lover; priestly vestments were certainly no bar to sexual relationships in the medieval period. ${ }^{33}$ Colle may also have been acting in his capacity as a spiritual advisor, intervening in a violent or adulterous marriage. Of course, it is also possible that this was simply an unhappy relationship, and Joanna chose to strike out against her husband in a way that would hurt him most: by targeting his purse.

${ }^{30}$ Walker, "Punishing Convicted Ravishers," pp. 245-46.

${ }^{31}$ S. F. C. Milsom notes that "many petitions of the fourteenth and fifteenth centuries complain of matters which in principle were remedied by the common law. Special treatment is sought because the petitioner is too poor to sue, or his adversary so powerful that sheriffs will not do their duty or jurors tell the truth." See S. F. C. Milsom, The Historical Foundations of the Common Law (London, 1981), p. 83.

${ }^{32}$ PRO, C1/75/39, Thomas Gwyn v. Thomas Colle, parson (ca. 1487-1504).

${ }^{33}$ See Edward Powell, "Jury Trial at Gaol Delivery in the Late Middle Ages: The Midland Circuit, 1400-1429," in Twelve Good Men and True: The Criminal Trial Jury in England, 1200-1800, ed. J. S. Cockburn and Thomas A. Green (Princeton, N.J., 1988), pp. $102-3$. 
The tendency of husbands to interpret the actions of an ecclesiastical official as a personal attack rather than institutional intervention was probably a common feature in cases of ecclesiastical arbitration in later medieval England. The petition of John Carvare, clerk chancellor to the archbishop of York, substantiates this conjecture. In his bill of complaint, John recounted the story of Joanna, wife of Guy Dawny, esquire. When she requested a separation from the archbishop of York because of her husband's cruelty, she claimed that her life was in imminent danger. Her testimony to the court alleged that her husband was guilty of trying to "manacal and threte her to mayhem and to slay" her. Given the volatility of the situation, the court ruled that it was in the best interests of both parties for Joanna to be sequestered from her husband within the city of York for the duration of the suit, as was often the custom in applications for judicial separation. ${ }^{34}$ Irrespective of the court's ruling, Guy decided to take matters into his own hands. Using the language of the common-law courts, in which a claim of violent trespass had to include the allegation of "force and arms" (vi et armis) (a legal requirement often fictitiously manipulated in order to have a case brought before the king's court), ${ }^{35}$ John recounts how with "force and armes" Guy came to the place where Joanna was staying and "ayenst her wyll wit great vyolence toke and set [Joanna] in to a karte and her caryed awaye and the same Johan then makyng theroff a great exclamation that a multitude of peple cam and retyened the said carte." Once again, the archbishop was called in to arbitrate. He decided that Joanna should return to her place of residence in the city of York until the suit was determined, and ordered Guy to leave his wife alone. John Carvare, as clerk to the archbishop, was appointed by the court to escort Joanna back to her home in York. His intervention so enraged Joanna's husband that Guy sued an action of trespass against Carvare and "intendith by myght and power that he hath in the same cytee to contemp yor said besecher in great cost and damage to his great hurte and losse." Facing imprisonment, and unable to turn to his superior (the archbishop having recently died), Carvare found himself in a dangerous situation. ${ }^{36}$

\footnotetext{
${ }^{34}$ Sequestration to prevent the plaintiff from experiencing undue force was a common procedure in the canonical courts. For example, in the period from 1463 to 1505, Canterbury act books record at least nine cases of sequestration. See Canterbury Y.1.6, fol. 21; Y.1.15, fols 160 and 201; Y.1.16, fol. 253; Y.1.17, fol. 13; Y.1.19 in which the folios are unnumbered but the cases are those of Ralph Huddingfeld of Smorden and his wife Amica Humfrey, and Lodan of Betrysden and his wife Elisabeth Barker; and finally, Y.2.2, fols. 37 and 110 .

${ }^{35}$ Milsom, Historical Foundations of the Common Law, pp. 283-313.

${ }^{36}$ PRO, C1/295/4, John Carvare, clerk chancellor to Thomas late archbishop of York (ca. 1504-9). Certiorari.
} 
In using the royal courts as a weapon to harass the church's officials, men like Guy Dawny hoped to discourage any further prying into their matrimonial affairs. Given the very low numbers of cases of judicial separations on the grounds of cruelty, it seems likely that this was an effective strategy. ${ }^{37}$ More to the point, the hostility that Guy exhibited to ecclesiastical intervention speaks to the resentment felt by some in English communities toward the church's encroachment into marriage. R. N. Swanson claims that the underlying tensions between priests and the male laity are grounded in the domestic milieu. He argues, "the collusion between clerics and women to civilize and Christianize medieval lay men could easily be interpreted as a conspiracy against male control over the family and domestic life: the clergy could be attacked as having too close attachments to women, encouraging their spirituality and acts of charity without reference to their husbands, thereby undermining male power." 38 Guy's reaction, then, likely represents a more general belief that marital disharmony was an issue best left to real men.

\section{The Court of Chancery and the Division of Marital Property}

Disputes concerning marital property were another issue over which a separated couple might find themselves reunited once more, if only in the courtroom setting. Thus, the records of early Chancery proceedings afford some evidence into the various ways in which men maintained their wives. ${ }^{39}$ For example, fairly typically, Thomas Leylond of Norfolk chose to care for his wife through enfeoffment. He granted the use of a messuage of land in Cley to another man on the condition that he provides meat, drink, and clothing for Thomas's wife Agnes. However, the feoffee failed to live up to his side of the bargain, and the court of Chancery was asked to step in when Thomas refused to pay for Agnes's support. ${ }^{40}$ Despite the failure of common-law courts to recognize uses, enfeoffment to use was a standard procedure in this period for all sorts of purposes. In fact, many marriage settlements in this period stipulated the creation of a use to

${ }^{37}$ Judicial separations were very infrequent. For example, for the ecclesiastical province of York from the fourteenth to the early sixteenth century, there are only six identifiable cases of applications for separation on the grounds of cruelty.

${ }^{38}$ R. N. Swanson, "Angels Incarnate: Clergy and Masculinity from Gregorian Reform to Reformation," in Masculinity in Medieval Europe, ed. D. M. Hadley (New York, 1999), p. 170.

${ }^{39}$ Given the predominance of women at Chancery in cases related to inheritance, Chancery may well have seemed the logical forum for the resolution of property disputes. Moreover, enfeoffment to use was defensible only at Chancery, owing to the failure of the common-law courts to recognize its existence.

${ }^{40}$ PRO, C1/266/23, Agnes wife of Thomas Leylond v. her husband Thomas Leylond (ca. 1500-1509). 
provide for a wife, whether separated or not. ${ }^{41}$ The fact that meat and drink were part of the maintenance required for Agnes would seem to indicate that she and Thomas Leylond were no longer coresiding; however, it is also possible that Thomas was a businessman who traveled frequently.

The separation agreement of Thomas Broune and his wife Elizabeth seems to have been more typical of the kind of alimony payments one sees in the ecclesiastical records, though decidedly more formal. When the couple resolved to "deforce ... from bed and borde," each had a deed of separation drawn up detailing exactly what Elizabeth would receive as a one-time only payment for her support. According to the petition of William Broune, Thomas's executor, it

was agreed betwene the seid Thomas \& Elizabeth that the same Thomas shuld delyver to the same Elizabeth and to oder persones to her use a certeyne money and plate and that the same Elizabeth from thensforth shuld neyther vex trouble ne sue the seid Thomas ne his executors for eny parte of his good catall money or plate and it was further aggreed betwen the same Thomas and Elizabeth that the same Thomas shulde bounden to Thomas Ffynes Knyght and Godard Oxenbrig Squier in an obligacon in the some of cc li. for the same agrement to be kept on the parte of the same Thomas and in like wyse the seid Elizabeth with oder for her shuld be bounden by obligacon to that Michell Priour of the hous of Seynt Mary Overe yet lyving and to Rychard Morland decessed in cc li. for the true performans of the seid agrement of the seid Elizabeth. ${ }^{42}$

Thomas's executor argued further that Elizabeth had received the money and plate as stipulated in the penal bond. His witnesses could attest that she had been given $£ 30$ and more, as well as "dyvers penys goblett salt and sponys to a gret value," and that she had been "fully content" with this agreement; that is, until her husband died. Elizabeth's suit in King's Bench against the executor for the sum of $£ 200$ she claimed was outstanding on the nonperformance of this agreement was the cause of William's petition to the chancellor.

Thomas's statement that Elizabeth "shuld neither vex trouble ne sue the seid Thomas" in the future was a shrewd inclusion on his behalf in

${ }^{41} \mathrm{R}$. H. Helmholz notes that the growth of trusts for women by the fifteenth century is substantial enough to explain, in part, why married women no longer felt inclined to make wills of their own. See his "Married Women's Wills in Later Medieval England," in Wife and Widow in Medieval England, ed. Sue Sheridan Walker (Ann Arbor, Mich., 1993), pp. 165-82. Timothy Haskett notes that uses, which often seem to have been established for women, were the most common subject of disputes in Chancery at 27.4 percent. See Haskett, "Medieval English Court of Chancery," p. 300.

${ }^{42}$ PRO, C1/289/33, William Broune, executor of Thomas Broune v. Elizabeth wife of Thomas Broune (ca. 1504-9). 
order to prevent any difficulties with double charging. A separated wife unhappy with a maintenance agreement doubtless believed that the best solution to the problem was to go shopping: who was to prevent Elizabeth from purchasing goods and simply charging them to her husband's name ${ }^{43}$ Most merchants or workmen were willing to allow wives to acquire relatively inexpensive goods ${ }^{44}$ (such as food stuffs, material for clothing, and other necessity items) or services in this manner; such an arrangement was common, and vital to the running of medieval households when husbands were frequently away or ill, leaving their wives to run the household and business. If the bill went unpaid, a creditor had legal recourse against the husband, because "by law she had nothing with which to pay." ${ }^{45}$ Thomas probably intended this clause precisely to prevent Elizabeth from continuing to enjoy these kinds of marital privileges, effectively charging him twice for her support. At the same time, Thomas's decision to opt for a maintenance agreement of this nature, however, highlights the difficulties of this kind of arrangement. A settlement of $£ 30$ or more and many expensive goods seems fair, yet it was insufficient to keep Elizabeth in the lifestyle to which she had become accustomed. Elizabeth's decision to go to court after Thomas's death makes it plain that the end of the money was now in sight. This couple's problem raises an interesting question: if a woman in Elizabeth's situation ran out of funds while her husband was still alive, was he obligated to support her beyond the agreement? Unfortunately, no cases of this type have survived in order to suggest what might have been the usual course. However, it seems likely that a man was compelled by custom (if not law) to support his wife. Although they no longer cohabited, she was still his wife.

${ }^{43}$ J. H. Baker notes that by 1300 , a wife could bind her husband "to a sale of goods which came to his use or profit." Cited in Janet S. Loengard, "Common Law for Margery: Separate but Not Equal," in Women in Medieval Western European Culture, ed. Linda E. Mitchell (New York, 1999), p. 123 (for a discussion of women's market rights, see pp. 12325 of Loengard). For a much lengthier discussion of this subject, see William C. Jordan, Women and Credit in Pre-industrial and Developing Societies (Philadelphia, 1992).

${ }^{44}$ The literary evidence from the time suggests that creditors permitted wives a good deal of flexibility in this respect. For example, in Chaucer's "The Shipman's Tale," the wife of a merchant tells Daun John that she needs 100 franks to pay off her dress bill, owing the following week. The implication is that she must pay it off before her husband finds out the bill even exists.

${ }^{45}$ Loengard, "Common Law for Margery," p. 124. While it is clear that creditors were quite happy to conduct business with medieval English wives in this manner, it is difficult to say whether a separation between husband and wife necessarily quashed this marital privilege. Buying on credit may well have been a practical method of supporting one's wife during a separation; merchants and workmen, however, may have been less assured of payment in these situations and refused to trade on these grounds alone. In Elizabeth's situation, certainly, before her separation was widely known, a fruitful trip to market might have allowed her to stock up on necessities, thereby sustaining herself for some time before needing to dip into Thomas's allowance. 
Another appeal by Thomas Thornton, a clergyman, confirms the notion that society expected husbands to support their separated wives. When James Mawncy of London crippled his wife, Agnes Bawdewyn, and then deserted her for more than a year, Thornton felt obligated as a chaplain to assist her in her time of need. In total, Thornton spent 20 marks to feed and shelter Agnes during her husband's absence, and he was enraged when Mawncy finally returned and refused to repay "any peny" of the 20 marks to Thornton. The situation quickly degenerated. Not only did Mawncy enter Thornton's home in London with "force and armys and made assault uppon the seyd Agnes his wiffe," ${ }^{46}$ he also falsely sued an action of trespass against Thornton, for which Thornton was arrested and imprisoned. The chaplain's request to the chancellor, then, was for a writ of corpus cum causa in order to have him released from prison, but also a subpoena directed to Mawncy requiring him to appear in court where he might be compelled to pay Thornton the money he owed for Agnes's support. ${ }^{47}$

The case of James Mawncy and his wife Agnes was far different from that of Elizabeth and Thomas Broune. There was no prearranged maintenance agreement, and the former was a case of desertion rather than separation. Yet, Agnes's priest was very confident of his rights to compensation. Maintenance of an abandoned wife was not a charitable matter. Maintenance agreements for separated wives existed for exactly this reason: communities did not wish to assume the responsibilities of the husband simply because the marriage had gone sour. Mawncy was fully responsible for his wife's support, even if he no longer resided with her. Thornton's sense of entitlement in this issue is striking. If Thornton's was a well-founded expectation, it is likely that, despite a formal arrangement renouncing any future support, a husband was still responsible for his separated wife's maintenance. In short, this was what being a husband was about in the medieval context.

The complaint of Lady Margery of Longford in Staffordshire against her husband Richard of Clyderhowe demonstrates why Chancery was the best option for settlement in some cases of separation. Although she did not provide the details of their faltering relationship, Lady Margery made it clear that she was living in fear of her husband and intended to obtain a judicial separation. Her apprehension, however, was that she would lose her property in the process. Since their physical separation, her husband had already taken some precautions by alienating a portion of their marital property to men described only as his friends. On the advice of her friends,

\footnotetext{
${ }^{46}$ Please see n. 35 above concerning the use of the term "force and arms."

${ }^{47}$ PRO, C1/365/37, Thomas Thornton chaplain v. James Mawncy of London carpenter (ca. 1504-9).
} 
before she took her case to the church courts for a "devors bytwene hy and hyr" she petitioned Chancery to assist her in creating an equitable separation agreement to keep her property intact. Her bill provides few particulars concerning the extent of Lady Margery's wealth; nonetheless, her anxiety and the necessity to provide for her husband through a curtesy indicate that she was affluent in her own right. In her mind, "a gode accord" between them consisted of an immediate $£ 40$ grant to her husband and, in accordance with the common-law requirement, the right to curtesy if Margery should die first. ${ }^{48}$

Because this is the only case of husband maintenance to have been uncovered in the course of this investigation, it is unfortunate that the chancellor's final judgment should remain a mystery. What his decision might have been in this matter is difficult to discern. At the very least, Lady Margery believed that hers was the just course of action and that she had every right to keep her property. Yet, because historians have not identified other cases of this sort in the medieval records of Chancery, and she was forced to turn to the chancellor for protection in this matter, it seems unlikely that this was regular practice in the later medieval period.

\section{Domestic Violence: The Case of Alice and George Softley}

The numerous cases of informal separation (under the guise of consensual abduction, desertion, or otherwise) reveal possible sources of matrimonial disharmony that provoked or intensified situations of physical abuse. While domestic abuse in the form of physical violence does not figure largely in these records, a number of cases acknowledge its existence. For example, both Elizabeth Broune and Margery of Longford assumedly received judicial separations from their husbands; in theory, only marriages plagued by heresy, adultery, and cruelty were eligible for separations, although the records make it clear that adultery on its own was not sufficient to meet the requirements of the church courts. ${ }^{49}$ Thus,

${ }^{48}$ PRO, C1/6/318, Lady Margery of Longford v. her husband Richard of Clyderhowe (ca. 1424-25) (the records do not offer surnames for either individual). This case also appears in an archiepiscopal register from the period. While Margery was in the process of obtaining a fair separation agreement, the church courts were attempting to enforce an action for restoration of conjugal rights. In fact, the archbishop's court even turned to the secular arm of the law in this matter after repeated injunctions failed to convince Margery to return to her husband. Whether the secular courts actually got involved in the case is hidden from the historian, but Margery's case certainly demonstrates that marital disputes could well find their way into a variety of courts in an attempt to find a just resolution. See The Register of Henry Chichele Archbishop of Canterbury 1414-1443, 2 vols., ed. E. F. Jacob (Oxford, 1938), 1:185.

${ }^{49}$ In an examination of applications of separation for both ecclesiastical provinces in the medieval period, I was incapable of finding a case of separation on the grounds of 
Elizabeth and Margery were probably complaining of physical abuse. The case of Alice, wife of George Softely of Latton in Essex, is one of the few cases to present in detail the victim's perspective on marital violence, although once again the case was not actually about the violence itself. Along with her son Richard, Alice was driven to the court of Chancery in order to safeguard her property (also Richard's inheritance) of "ii meser and $\mathrm{lx}$ acres lond wode mede and pastur in Latton" from a "moste shamefull and unmanly" fellow who just happened to be Alice's husband. After the death of her first husband, Thomas Westwode of Latton (father to her son Richard), Alice contracted marriage to George Softley, a man of much lesser means, "havyng no substans but the good possessionis that he had with the seid Alice." The state of the marriage at the time of the bill, however, suggests that George married her only for her money. According to the bill of complaint, he

entreteth the same Alice in moste shamefull and unmanly wise and kepeth her so streit that she hath not her sustennance of mete and drynk like a woman but without cause often tymes grevously bethe her and in hervest last past so hurt and bette her that she was therby in perell of her liff and drove her owte of her owne hous wherby she so beten and driven away and not havyng a kerchef on her hede nor clothes hable to cover her body came to the seid Richard her son dwellyng within a myle of her hous for socour. ${ }^{50}$

Her son received her into his home but soon after returned to her household with reinforcements to talk to his stepfather and convince him "to kepe and cherissh his seid wyff like a woman." George's immediate response was overt hostility. He "rebuked and reviled the seid Richard and bete him and drove him oute of his hous and wold have slayed him if he had not hastily aborded." Thereafter, the situation rapidly deteriorated. According to their bill of complaint, Richard and his mother were living in daily fear for their lives. Aided by two acquaintances, George constantly harassed the two. More seriously still, Richard was convinced that his inheritance was quickly being spent. George had allegedly taken evidence concerning the inheritance from Richard's mother and refused to surrender a copy to his stepson. To make matters worse, he had pleaded so many false suits in court against his stepson that Richard feared it would soon

adultery alone. Typically, allegations of adultery were combined with those of physical abuse. For example, see YBI, CP. E 257, Margery de Devoine v. Richard Scot (1349), or YBI, CP. F 56, Cecilia Wyvell v. Henry Venables (1410).

${ }^{50}$ PRO, C 1/162/46, Alice wife of George Softley of Latton previously wife of Thomas Westwode of Latton, and Richard son of the said Thomas and Alice v. George Softley of Latton (ca. 1504-9). 
"empoveryssh hym so that he shulde never be hable to sue for his right of his seid reversion." Devoid of remedy in the courts of common law, Alice and Richard turned to the chancellor in hopes of ridding themselves of this unwanted parasite.

It is noteworthy that in this case Alice and Richard were joint petitioners, and that Richard's fears concerning his inheritance occupy fully the second half of the bill. In consequence, the bill diminishes Alice's own plight and binds it inextricably to Richard's larger concerns. The account conveys the sense that she is merely the custodian of his property, and through her ill-fated choice in marital partners, she endangered that which was rightfully his. This is an important distinction to make. It is possible that if her son's economic welfare had not been in danger, Alice's case would never have come before the chancellor. She was only included in this case because the property was in her name (if not in her possession), and consequently Richard was not justified in petitioning for property that was not yet his. ${ }^{51}$ More pointedly, while the bill emphasizes George's abuse of his wife, it uses the abuse here primarily to illustrate his contemptibility and irrationality; it is not the reason she and her son were in court. The appearance of this case in the court of Chancery does not imply that medieval society considered the forum appropriate for the resolution of marital ill treatment. The petition confirms this, by describing George's abuse of Richard more harshly than that of Alice. While Alice was beaten and driven from her home in a state of disrepair, Richard was almost slain. If the intention had been to secure protection for Alice from an abusive husband, the narration of the events would have reversed the degrees of severity.

Still, a secondary motivation for this petition was doubtless to bring to a halt the constant harassment of Richard and Alice by George and his company of brutes. The bill specifically requests that George, Richard Brown of Netteswell, and Aleyn Tanner of Latton be required to "fynd sufficient suretie of their good aberyng and to kepe the kyng peas." Oddly, nowhere does the petition address the fact that Alice was still, at least legally, married to the leader of this criminal trio. Alice and Richard clearly expected George's behavior to improve, but it is apparent that Alice did not intend to resume her former relationship with him. From her perspective, his untoward conduct was inexcusable.

The case of George and Alice, incidentally, reveals a great deal about contemporary constructions of gender identities. George is depicted not

\footnotetext{
${ }^{51}$ Most likely, the property to which Alice and Richard refer constituted part of Alice's dower lands, upon which she was a life tenant. In this situation, Richard would stand to inherit the estate after his mother's death.
} 
only as a dishonest crook and shoddy husband but also as an utter failure as a man. The petition describes his lack of self-control in his violent behavior toward his wife and dereliction in his obligation to maintain her and provide her with the necessities of life as "moste shamefull and unmanly wise." In this context, being a man was much more about caring for a family than it was about masculine aggression. This insight helps to untangle medieval perceptions of masculinity. Sermon writers like Peregrinus and Berthold of Regensburg both suggest that men in the later Middle Ages were often torn between two competing notions of masculinity: one in which masculinity was defined by an intuitive aggression in a physical sense, and another focusing instead on the good husband who provides for his family. ${ }^{52}$ The case of George Softely confirms the existence of a discursive hierarchy in the home. When rival gender identities came head-to-head in the home environment, medieval society expected the good husband to prevail. In the domestic milieu, the physically aggressive male was not a man at all.

When Richard returned home with his mother and asked his stepfather to reform his behavior, he also chose to phrase his request in gendered terms. He wished George "to kepe and cherissh the seid wyff like a woman." In explicitly reminding George of Alice's femininity, he was appealing to the latter's role as protector. George's repudiation of Richard's appeal illustrates that this was a role he had never wished to fill.

\section{The Role of the Family in Domestic Disputes}

The case of Alice and George Softley also demonstrates the integral part played by both the family and the community in the management of marital discord. ${ }^{53}$ When George drove Alice from her home unclothed, she instinctively turned to her son for assistance. Likewise, when Richard chose to confront his stepfather about his ill conduct, he did not approach him alone, but in the safe company of his neighbors, a feature that apparently required no explanation. Obviously communal intervention was the regular procedure for dealing with these kinds of familial disputes,

\footnotetext{
${ }^{52}$ See Andrew Galloway, "Marriage Sermons, Polemical Sermons, and The Wife of Bath's Prologue: A Generic Excursus," Studies in the Age of Chancer 14 (1992): 3-30; Rüdiger Schnell, "The Discourse on Marriage in the Middle Ages," Speculum 73 (1998): $771-86$.

${ }^{53}$ Both Barbara Hanawalt and Jeremy Goldberg have theorized that families most likely continued to play an important role as advisors and mediators in domestic disputes. See Barbara A. Hanawalt, The Ties That Bound: Peasant Families in Medieval England (Oxford, 1986), pp. 208-10; P. J. P. Goldberg, Women, Work, and Life Cycle in a Medieval Economy: Women in York and Yorkshire c. 1300-1520 (Oxford, 1992), p. 267.
} 
and it was only George's prolonged mistreatment that required intervention by a higher authority.

The Softley dispute was not the only case to appear in the late medieval court of Chancery in which a family member or friend was forced to intervene in a matter of domestic violence. When John Baker of London became aware that his sister was suffering abuse at the hands of her husband, he found himself drawn into a situation that quickly turned against him.

One Thomas Seynt Nicholas have maried the sister of your said Oratour betwene whome nowe of late fell greate unkyndnes in somoche that the said Thomas Seint Nicholas for a mater of smale substannce did bete his wyff so grevously that it was thought that she wold dye and your said Oratour heryng of the mysdemeanour of the said Thomas Seint Nicholas came unto hym in good maner and entreated hym with good wordes to be good and kynde lover unto his sister and nomore to demeane hym selfe after such manner and he wolde be unto the said Thomas as good a frend as he had ben in tymes past and the said Thomas Seint Nicholas answerd your said Orator that he wolde punysshe his wyff at his pleasour and the more for his ... [saying it] and then in a greate fury departyd frome your said Oratour and so it is good and gracious lord that your said Orator came to London for such busines as he had there to do and the said Thomas Seint Nicholas therof knowing sent to London one Willim Seint Nicholas brother of the said Thomas and desyred hym onely for vexacion and trouble to attach your said Orator upon suspicion of felony and so the said William hath nowe your said Orator upon the said feyned surmyse in the compter in London and there hath contynued by the space of xvi dayes and more. ${ }^{54}$

His petition concluded with a heartfelt plea to the chancellor to consider John's circumstances and accordingly to grant him a writ of corpus cum causa to release him from his unjust imprisonment.

John describes the beating inflicted upon his sister as being of a grave nature. His intervention, then, was that of a concerned brother wishing to prevent a recurrence of this abusive behavior. That he chose to confront his brother-in-law rather than remove his sister altogether from a harmful environment is revealing. If the first known instance of abuse was severe enough to endanger her life, and the reason for the abuse was reportedly "a mater of smale substannce" (as opposed to a serious argument spiraling out of control), then separation was the logical solution to the problem. John's decision not to help his sister pursue this route supports the argument that there was an established process of intervention, and family

${ }^{54}$ PRO, C1/287/47, John Baker, clerk (ca. 1504-9). 
involvement was only the first stage. Moreover, John's mention of this episode as justification for his actions demonstrates that a forceful tête-àtête with his ill-mannered brother-in-law was fully expected. Unfortunately, the record reveals little about John's response to the declaration that Thomas "wolde punysshe his wyff at his pleasour." Nevertheless, that was not the intention of this comment. It was included in his petition in order to make a point about the flawed nature of his brother-in-law's character, in the hopes that this flagrant disregard for social ethics would portray the latter as not only a wretched husband but also a disagreeable person.

John's petition to Chancery seems oddly incomplete. The request for a writ of corpus cum causa to release him from jail was appropriate and predictable. However, one would expect to see a secondary request to have Thomas and his brother William brought before the chancellor and compelled into good behavior, much like the clause Richard and Alice included in their case against George Softley and his associates. Without an explicit reproach of Thomas and William's shady involvement in John's current predicament, there was no reason for them to discontinue their dogged harassment of John and his sister. An appearance in court before the chancellor, supplemented by a demand for sureties, would have eliminated the source of both problems (John's imprisonment and the endangerment to his sister's life). The omission of such a request invites an obvious conclusion. John did not appeal to the chancellor for help in his sister's domestic situation because it was not the appropriate venue. Thomas and William's behavior was a communal problem best dealt with informally, or before the manor court; only John's imprisonment might not be resolved so easily. His failure to address the issue of spousal mistreatment suggests that Thomas's actions had not yet exceeded communal controls, even though Thomas "did bete his wyff so grevously that it was thought that she would dye." 55

\section{Conclusion}

The court of Chancery opens a new window onto domestic disputes in the late medieval period, offering a vision of a world where abuse of the

\footnotetext{
${ }^{55}$ It is possible that Thomas's wife had already begun a suit in ecclesiastical court for a judicial separation on the grounds of cruelty, although I was incapable of finding evidence of such a suit. However, John Baker's initial actions strongly suggest that he did not feel the beating required ecclesiastical intervention; his opinion may have changed with subsequent dealings with his brother-in-law. The bill certainly does not indicate that a suit had been initiated in the church courts, and it seems likely that an appeal to the regular process might well have been mentioned in this case only because it would have strengthened Baker's negative depiction of his brother-in-law.
} 
common-law courts was standard practice. Almost all the petitioners involved here threw themselves on the chancellor's mercy when faced with imprisonment through the suits of a spouse or his/her representatives, attesting that domestic violence in the medieval setting might sometimes adopt a legal dimension. Moreover, these cases demonstrate much about the regular process of marital breakdown. It is clear that some cases of marital disharmony led to separation, and it was at this point that money moved to the forefront of the discussion and became the central issue of dispute. Legal battles over maintenance and division of property were evidently every bit as petty and bitter as those appearing in court today. The fact that it was usually women in medieval England who turned to the court in property issues after the settlement of a separation highlights the legal vulnerability of women in a society where marital property belonged absolutely to the husband. At the same time, however, cases of consensual abduction demonstrate that husbands found themselves equally constrained by the fictions of the unity of person in marriage. The rules of coverture made it impossible for harassed or impoverished husbands to sue the real culprit in their lives.

When it comes to historical analysis, Chancery cases share many of the same difficulties of common-law cases. Petitioners employed legal fictions both to get cases into Chancery and to gain a sympathetic ear; nevertheless, this manipulation of the law also works to the advantage of the historian. Matrimonial disputes appearing in the court of Chancery reveal much about social expectations of both husbands and wives. Medieval society expected husbands to care for their wives, whether they wished to fill this role or not. While discipline of a wife was accepted and even encouraged, abuse was surely not, and both families and communities in general were willing to protect a woman when her spouse overstepped the boundaries of good governance. Wives, on the other hand, were expected to submit to governance. The reality of these bills of complaint, however, uncovers that many women did not wish to be subservient to their husbands. Informal separations, blatant desertions, and threats or attempts on the life of a spouse suggest that some medieval wives were unwilling to remain passive when confronted with their husbands" "moste shamefull and unmanly wise." The old adage that "all is fair in love and war" rings true in the medieval context. 
Copyright of Journal of British Studies is the property of North American Conference on British Studies and its content may not be copied or emailed to multiple sites or posted to a listserv without the copyright holder's express written permission. However, users may print, download, or email articles for individual use. 